\title{
Cyclin Dependent Kinase Inhibitors and Dominant Negative Cyclin Dependent Kinase 4 and 6 Promote Survival of NGF-Deprived Sympathetic Neurons
}

\author{
David S. Park, ${ }^{1}$ Beth Levine, ${ }^{2}$ Giovanna Ferrari, ${ }^{3}$ and Lloyd A. Greene ${ }^{1}$ \\ ${ }^{1}$ Department of Pathology and Center for Neurobiology and Behavior and ${ }^{2}$ Department of Medicine, Columbia University \\ College of Physicians and Surgeons, New York, New York 10032, and 3Fidia SPA in AS 35031 Abano \\ Terme-Via Ponte Della, Italy
}

\begin{abstract}
Neuronal apoptosis plays a critical role in both normal development and disease. However, the precise molecular events controlling neuronal apoptosis are not well understood. Previously, we hypothesized that cell cycle regulatory molecules function in controlling the apoptotic pathways of trophic factordeprived neurons. To test this hypothesis, we used the RNA alphavirus Sindbis to express three known cyclin dependent kinase inhibitors (CKls), p16 ${ }^{\text {ink4 }}, \mathrm{p} 21^{\text {waf/cip }}$, and p2 $7^{\text {kip } 1}$, and dominant negative mutant forms of four known $G_{1}$ cyclin dependent kinases (CDKs), Cdk2, Cdk3, Cdk4, and Cdk6, in primary cultured rat superior cervical ganglion sympathetic
\end{abstract}

neurons. We demonstrate that expression of each of the CKIs protects the postmitotic cultured neurons from apoptotic death evoked by withdrawal of NGF. In addition, we show that expression of dominant negative forms of Cdk4 or Cdk6, but not Cdk2 or Cdk3, protects NGF-deprived sympathetic neurons from death. Such findings suggest the participation of several CDKs and their cognate cyclins in a neuronal apoptotic pathway.

Key words: apoptosis; CDK; sympathetic neuron; Sindbis; cell cycle; cell death
Neuronal apoptosis plays critical roles in development and disease of the nervous system (for review, see Oppenheim, 1991; Stefanis et al., 1997). One model of developmental neuronal death involves the requirement for support by neurotrophic factors. In support of this, in vivo (Levi-Montalcini and Booker, 1960; Gorin and Johnson, 1979, 1980) and in vitro (LeviMontalcini and Angeletti, 1963; Martin et al., 1988) evidence demonstrates that survival of sympathetic neurons requires the prototypical neurotrophin nerve growth factor (NGF). In addition, these neurons undergo apoptotic death after withdrawal of NGF (Edwards et al., 1991; Batistatou and Green, 1993). The underlying biochemical mechanisms by which neurotrophins prevent cell death, however, are not well understood.

Studies on the mechanism by which neurons die when deprived of neurotrophic support reveal the involvement of several regulatory components. These include caspases (Gagliardini et al., 1994; Troy et al., 1997), pro- and antiapoptotic members of the bcl-2 family (Batistatou et al., 1993; Frankowski et al., 1995; Greenlund et al., 1995; Deckworth et al., 1996), and a requirement for transcription of specific genes including $c$-jun (Estus et al., 1994; Ham et al., 1995). Additional evidence suggests the participation of cell cycle proteins in the death of trophic factor-

\footnotetext{
Received June 26, 1997; revised Aug. 27, 1997; accepted Sept. 16, 1997.

This work was supported in part by grants from the National Institutes of Health National Institute of Neurological Diseases and Stroke, March of Dimes, Blanchette Rockefeller Foundation, Amyotrophic Lateral Sclerosis Foundation, and the Aaron Diamond Foundation to L.A.G. and from the National Institutes of Health, James S. Mcdonnell Foundation, and Irma T. Hirschl Trust to B.L. D.S.P. is an Aaron Diamond Foundation Fellow. We thank Dr. Harlow for the dominant negative CDKs and Dr. Massague for p27, Dr. Elledge for p21, and Dr. Beach for p16 constructs.

Correspondence should be addressed to Dr. David S. Park, Department of Pathology and Center for Neurobiology and Behavior, Columbia University College of Physicians and Surgeons, 630 West 168th Street, New York, NY 10032.

Copyright (c) 1997 Society for Neuroscience $0270-6474 / 97 / 178975-09 \$ 05.00 / 0$
}

deprived neurons. Previously, we demonstrated that multiple agents that promote the survival of primary cultured sympathetic neurons and neuronal PC12 cells deprived of trophic support also block cell cycle progression (Rydel and Greene, 1988; Ferrari and Greene, 1994; Farinelli and Greene, 1996). In addition, changes in cyclin dependent kinase (CDK) activity and cyclin expression occur in trophic factor-deprived neuronal cells (Brooks et al., 1993; Gao and Zalenka, 1995), and cyclin D1 transcript levels increase in NGF-deprived sympathetic neurons (Freeman et al., 1994). Consistent with the involvement of CDKs, the CDK inhibitory drugs flavopiridol and olomoucine promote survival of NGF-deprived neuronal PC12 cells and sympathetic neurons (Park et al., 1996a) and inhibit caspase activation (Stefanis et al., 1996). Accordingly, we and others hypothesized that neurons deprived of trophic support use cell cycle regulatory components to activate death pathways (Rubin et al., 1993; Ferrari and Greene, 1994; Freeman et al., 1994; Farinelli and Greene, 1996; Park et al., 1996a) and that cell cycle components act upstream of caspase activation (Stefanis et al., 1996).

Although suggestive, such studies have inherent weaknesses in that many rely on pharmacological agents and/or tumor-derived cell lines that do not necessarily reflect the postmitotic nature of neurons. To avoid these issues, we desired to express specific cell cycle regulatory genes in NGF-dependent, cultured rat sympathetic neurons. To do this, we used Sindbis virus, a positive-sense RNA virus in the alphavirus genus. Sindbis virus is neuronotropic and replication competent and, by construction of a double subgenomic Sindbis promoter, permits high-level expression of heterologous genes (Xiong et al., 1989; Levine et al., 1991, 1993, 1996; Hahn et al., 1992; Piper et al., 1992; Schlesinger, 1993; Cheng et al., 1996; Joe et al., 1996). Sindbis targets neurons in mouse brain (Jackson et al., 1987, 1988) and is an effective tool for the study of antiapoptotic genes in neurons in vivo (Levine et 
al., 1996). In addition, in contrast with the usual lytic replication observed in dividing cells (Levine et al., 1993), Sindbis infects sensory neurons in vitro in a persistent nonlytic manner (Levine et al., 1991).

Because previous evidence suggested that CDK activity is required for neuronal death (Park et al., 1996a), we focused our examination on this family. The CDK family, which includes $\mathrm{Cdk} 2, \mathrm{Cdk} 3, \mathrm{Cdk} 4, \mathrm{Cdk} 6$, and Cdc2 among others, is an important group of molecules that regulate the proliferation of dividing cells (Pines, 1993). Cdk2, Cdk3, Cdk4, and $\mathrm{Cdk} 6$ control $\mathrm{G}_{1}$ and $\mathrm{S}$ phases of the cell cycle, whereas $\mathrm{Cdc} 2$ is an $\mathrm{M}$-phase regulator (van den Heuvel and Harlow, 1993). In addition, two classes of mammalian cyclin dependent kinase inhibitors (CKIs) have been described (for review, see Sherr and Roberts, 1995). Cip/kip members, which include p21, p27, and p57, inhibit the activities of a wide range of $\mathrm{CDK}$-cyclin complexes. In comparison, ink4 family members, including p15, p16, p18, and p19, seem to inhibit primarily the activities of $\mathrm{Cdk} 4 / 6$ - cyclin D complexes. Although it is unclear which CKI members are present in sympathetic neurons, Freeman et al. (1994) have reported the presence of $\mathrm{Cdk} 4$ transcripts but were unable to detect those of $\mathrm{Cdk} 2$ or $\mathrm{Cdc} 2$.

In the present studies, we examined whether Sindbis virusmediated expression of inhibitors from these two major classes of CKIs and of dominant negative forms of several individual $G_{1}$ CDKs (Cdk2, 3, 4, and 6) would prevent the death of NGFdeprived sympathetic neurons.

\section{MATERIALS AND METHODS}

Generation of recombinant Sindbis. The coding regions of p16, p21, and p27 were subcloned into the BSTE11 site of the DSTEQ12 Sindbis virus vector (Joe et al., 1996) downstream of a double subgenomic Sindbis viral promoter. The coding regions of $\mathrm{Cdk} 2, \mathrm{Cdk} 3, \mathrm{Cdk} 4$, and $\mathrm{Cdk} 6$ and the single-chain ScFv control (R6) (X. H. Liang and B. Levine, unpublished data) cDNA were inserted into the XbaI site of the DSTEQ12 vector. The chloramphenicol acetyl transferase (CAT), Bcl- $x_{L}$, and $B c l$-2 recombinant viruses were generated previously (Cheng et al., 1996; Levine et al., 1996). FLAG tags (ATGGACTACAAGGACGATGATGACAAA) were introduced at the $3^{\prime}$ end of the coding region of $\mathrm{p} 27$, $\mathrm{p} 16, \mathrm{Cdk} 2, \mathrm{Cdk} 3, \mathrm{Cdk} 4$, and Cdk6. Control nonexpressing vectors of the CDK inhibitors were generated by eliminating the initiating codon of each inhibitor and, in p16, p21, Cdk3, Cdk4, and Cdk6, by introducing a premature stop codon. All mutations, deletions, and FLAG tags were introduced by PCR as described previously (Joe et al., 1996) and confirmed by sequencing. Viral particles were generated by in vitro translation and transfection into baby hamster kidney (BHK) cells and titered by plaque assay as described previously (Joe et al., 1996).

Culture and survival assay of rat sympathetic neurons. Primary cultures of rat sympathetic neurons were obtained from dissociated superior cervical ganglia of postnatal day 1 rats (strain, Sprague Dawley) as described previously (Park et al., 1996a). The cells were plated in $0.5 \mathrm{ml}$ of medium per well in collagen-coated 24 -well dishes at a density of $\sim 0.5$ ganglia per well ( $\sim 10,000$ neurons/well). The growth medium was RPMI 1640 medium supplemented with $10 \%$ heat-inactivated horse serum and $60 \mathrm{ng} / \mathrm{ml}$ mouse NGF (Sigma, St. Louis, MO). To eliminate nonneuronal cells, we added a mixture of uridine and 5-fluorodeoxyuridine (10 $\mu \mathrm{M}$ each) to the cultures on the following day. On the third day after plating, the neurons were infected with Sindbis virus (1-2 plaqueforming units per cell) in $0.2 \mathrm{ml}$ of RPMI 1640 medium containing $2 \%$ heat-inactivated horse serum. After $1 \mathrm{hr}$ of infection, $0.3 \mathrm{ml}$ of RPMI 1640 medium containing $16 \%$ heat-inactivated horse serum was added, and cultures were incubated overnight. The neurons were deprived of NGF by washing the cultures three times with RPMI 1640 medium containing $10 \%$ heat-inactivated horse serum. NGF or anti-mouse NGF antibody (1:200 dilution) was added in a final volume of $0.5 \mathrm{ml}$. At appropriate times, the numbers of viable, phase-bright neurons were determined by strip counting as described previously (Park et al., 1996a).

Immunofluorescence. Sympathetic neurons were dissociated and cultured, as described above, in six-well plates at a density of two ganglions

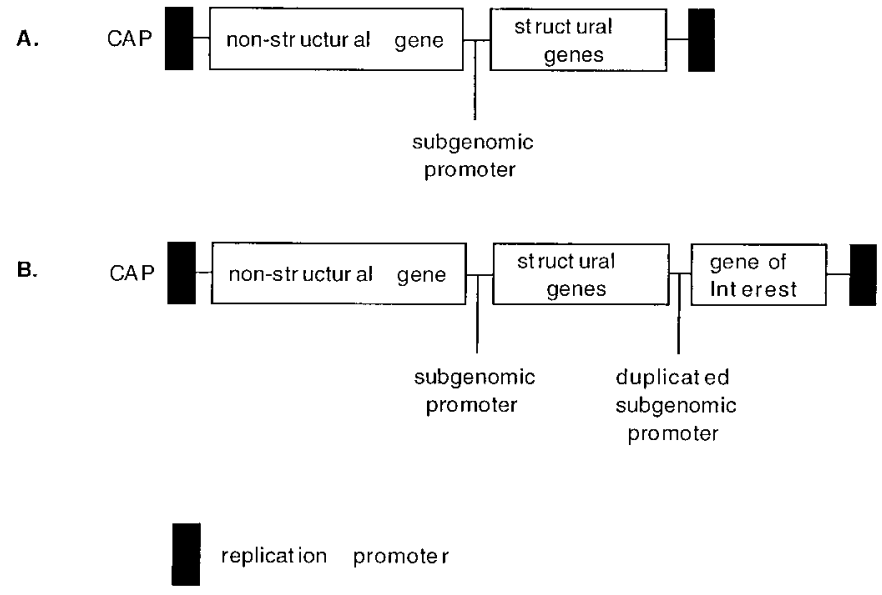

Figure 1. Diagram of the double subgenomic promoter containing Sindbis virus vector. $A$, Wild-type Sindbis vector. $B$, Sindbis vector with duplicated subgenomic promoter.

per well. After various times of infection, neurons were fixed with $100 \%$ ethanol for $20 \mathrm{~min}$ at $-20^{\circ} \mathrm{C}$, blocked with PBS containing $2 \%$ horse serum, and incubated with anti-FLAG primary antibody (1:20 dilution) (Fisher Scientific, Houston, TX) and FITC-conjugated horse anti-mouse secondary antibody (1:50 dilution) (Vector Laboratories, Burlingame, CA)

\section{RESULTS}

\section{Sindbis virus as an efficient gene delivery system for the study of neuronal apoptosis}

To test the hypothesis that CDK activity is a required element for neuronal death evoked by trophic factor deprivation, we used Sindbis virus to express CKIs and dominant negative forms of $\mathrm{G}_{1}$-associated CDKs in sympathetic neurons and evaluated the effects of expression on neuronal death. The Sindbis virus vector we used was previously engineered to contain two subgenomic SIN promoters (Fig. 1; Joe et al., 1996). The first 5' subgenomic promoter drives transcription of the structural genes required for Sindbis viral particle formation. Three-prime to the first subgenomic promoter is a second promoter that drives transcription of an inserted exogenous gene. To produce viral particles, we first transcribed in vitro Sindbis virus vectors containing the exogenous genes of interest and then transfected the vectors into BHK cells. After $24 \mathrm{hr}$, the cell culture medium that contains active virus particles was collected and titered by plaque assay. To confirm the effectiveness of Sindbis virus for delivery of exogenous genes into sympathetic neurons, we expressed $b c l-x_{L}$, an antiapoptotic gene known to promote survival of sympathetic neurons deprived of trophic support (Frankowski et al., 1995), from a previously described recombinant virus (see Fig. 1; Cheng et al., 1996). As shown in Figure 2, sympathetic neurons infected with $b c l-x_{L^{-}}$ containing virus [at a multiplicity of infection (MOI) of 1 plaqueforming unit/cell] and deprived of NGF $1 \mathrm{~d}$ later showed a significantly decreased rate of death compared with neurons that were either uninfected or infected with the same MOI of viruses containing the $b c l-x_{L}$ insert but with a premature stop codon. Thus, $\sim 70 \%$ of the neurons infected with the recombinant $b c l-x_{L}$ virus survived at $2 \mathrm{~d}$ after withdrawal of NGF, whereas only $\sim 25 \%$ survived in control cultures. The antiapoptotic $b c l-2$ gene (Greenlund et al., 1995) delivered by Sindbis virus infection also suppressed the death of NGF-deprived sympathetic neurons (data not shown). 
A

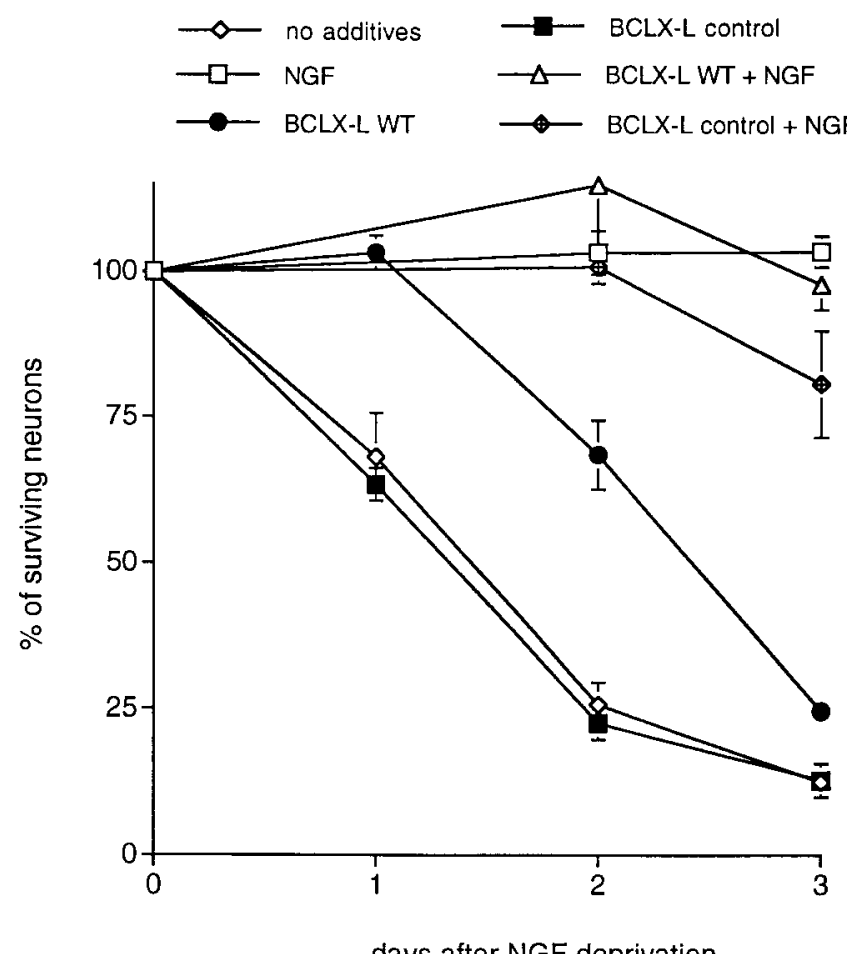

C

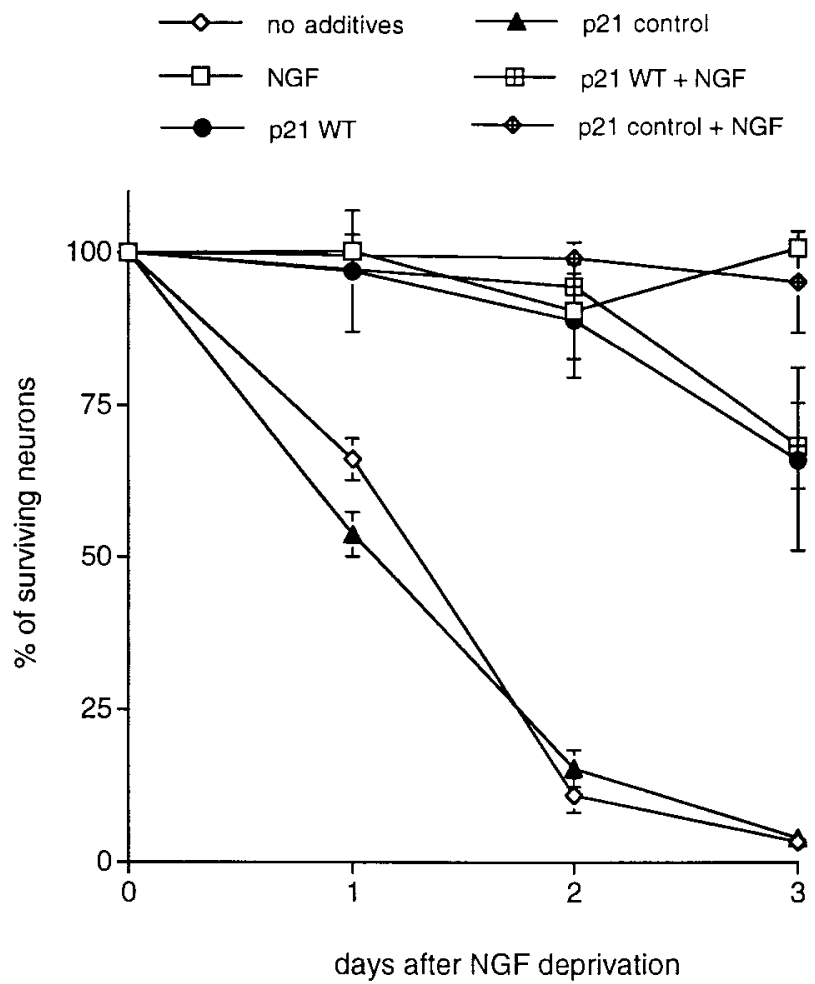

B

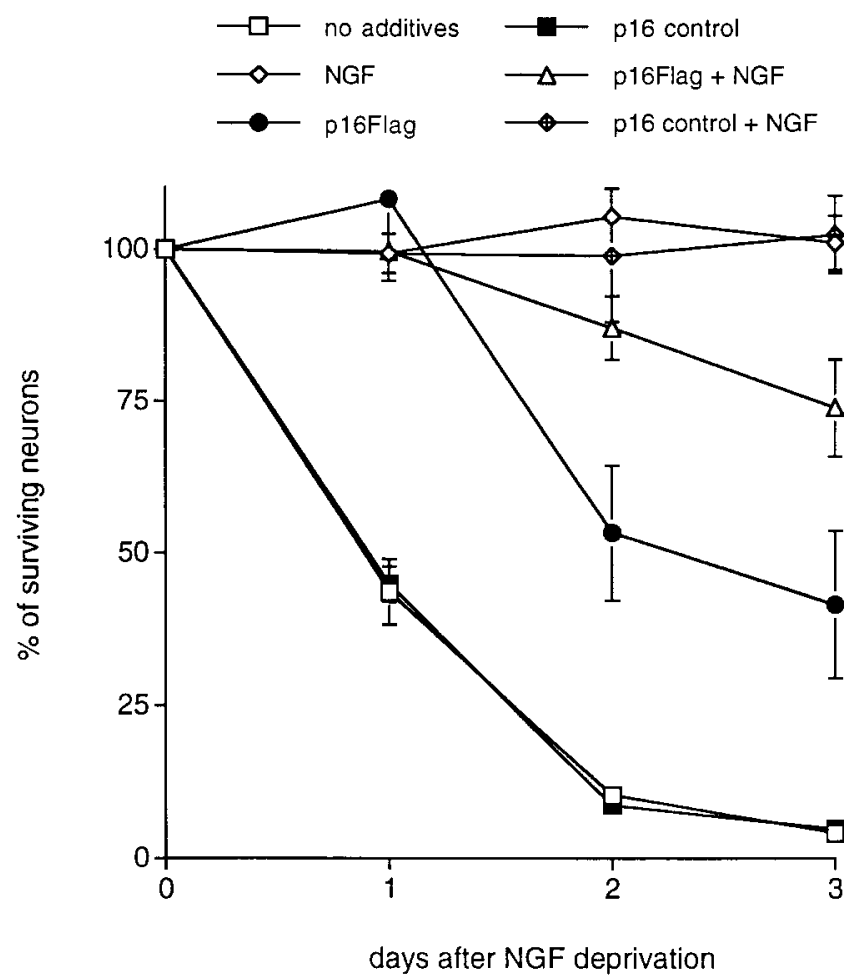

D
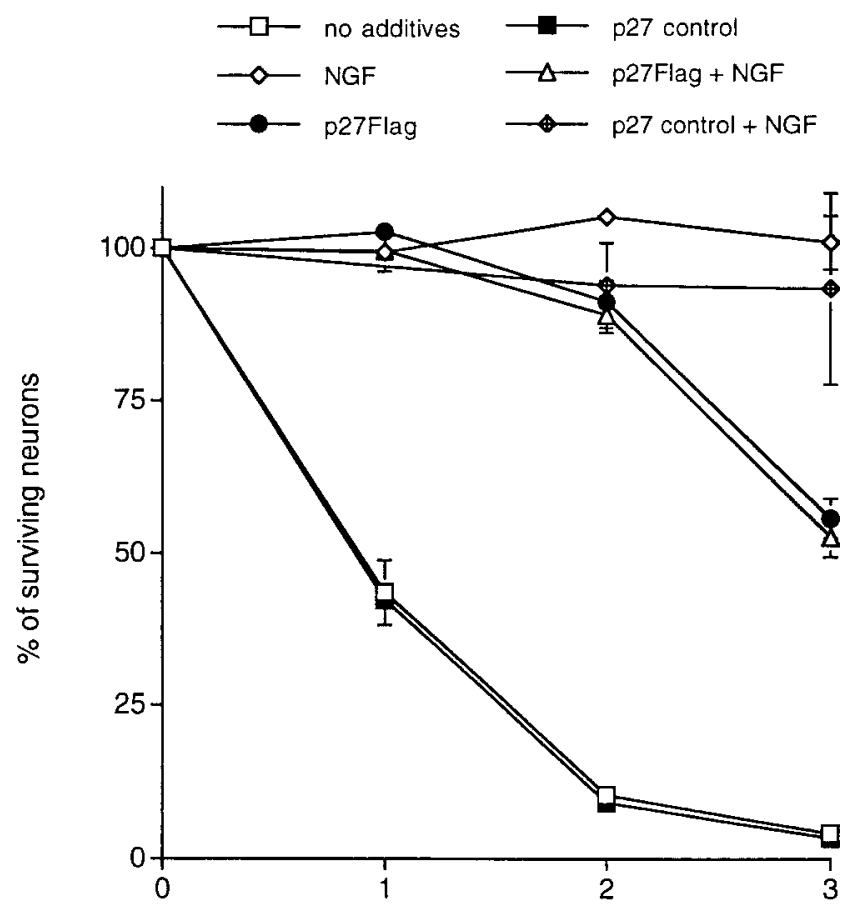

days after NGF deprivation

Figure 2. Expression of CDK inhibitors and $B c l-x_{L}$ using the Sindbis viral delivery system promotes survival of primary cultured sympathetic neurons deprived of trophic support. Each data point is the mean \pm SEM of three samples and is expressed relative to the number of neurons present in each well at the time of NGF withdrawal. Control viruses for each vector were generated by removal of the start codon and, in some cases, by introduction of a premature stop site. Flag denotes that the wild-type $(W T)$ protein has a flag epitope attached to the C terminal. The values of $p$ derived from Student's $t$ tests comparing the wild-type or flagged protein with the control-stop virus at days 1 and 2 are given. $A-D$, Effects of overexpression of $B c l-x_{L}$ $(p<0.01)(A), \mathrm{p} 16(p<0.05)(B), \mathrm{p} 21(p<0.005)(C)$, and $\mathrm{p} 27(p<0.05)(D)$ and respective controls on the time course of survival of sympathetic neurons after withdrawal of NGF. Similar results were obtained in at least three independent experiments. 

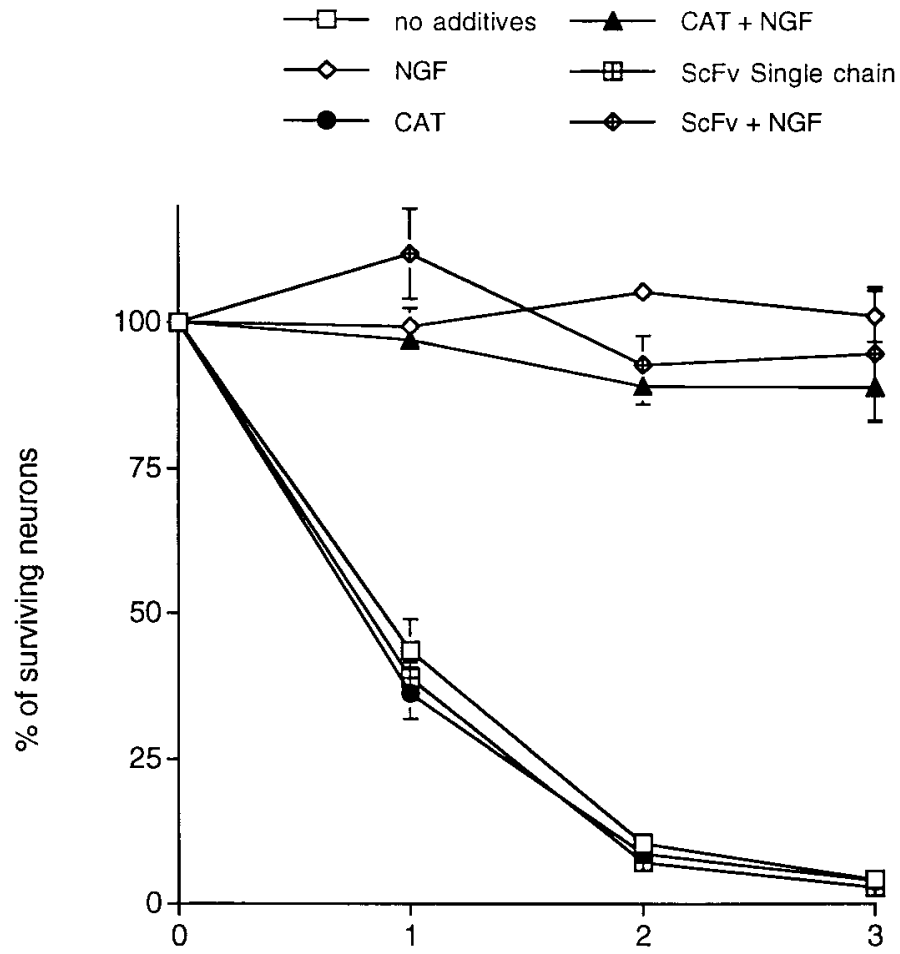

days after NGF deprivation

Figure 3. Sindbis virus-mediated expression of non-cell cycle-related control proteins, $C A T$ and an $S c F v$ single-chain antibody control, fails to promote survival of primary cultured sympathetic neurons deprived of trophic support. Each data point is the mean \pm SEM of three samples and is expressed relative to the number of neurons present in each well at the time of NGF withdrawal.

To assess the possibility that the observed survival effects were simply caused by heterologous gene overexpression, we infected neurons with control recombinant viruses expressing CAT, a single-chain antibody ( $\mathrm{ScFv}$ ) of similar size to the CKIs, or Beclin, a novel Bcl-2-interacting protein (Liang and Levine, unpublished data). These had no effect on the rate of death after NGF removal (Fig. 3) (data not shown).

Although past work has shown that Sindbis virus can replicate nonlytically in certain cultured neurons (Levine et al., 1991), we observed, in some cases in our experiments, cytopathic effects 4-5 d after infection, despite the presence of NGF. The extent of cytotoxicity was variable between experiments and viral constructs. However, we observed minimal correlation between the toxic effects of Sindbis and the survival of sympathetic neurons. For example, in some experiments, infection with control Sindbis constructs caused significant toxicity of NGF-treated sympathetic neurons after $4 \mathrm{~d}$ but did not affect the rate of death of NGFdeprived sympathetic neurons. Finally, because NGF deprivation in our experimental paradigm results in death of substantial numbers of neurons by $24 \mathrm{hr}$ and death of almost all neurons by $48 \mathrm{hr}$, there was an ample window of time in which to evaluate whether delivered genes can suppress apoptosis.

\section{CKI expression protects sympathetic neurons from death evoked by NGF deprivation}

We next assessed the effects of virally delivered CKI genes and dominant negative forms of CDKs. Recombinant Sindbis viruses
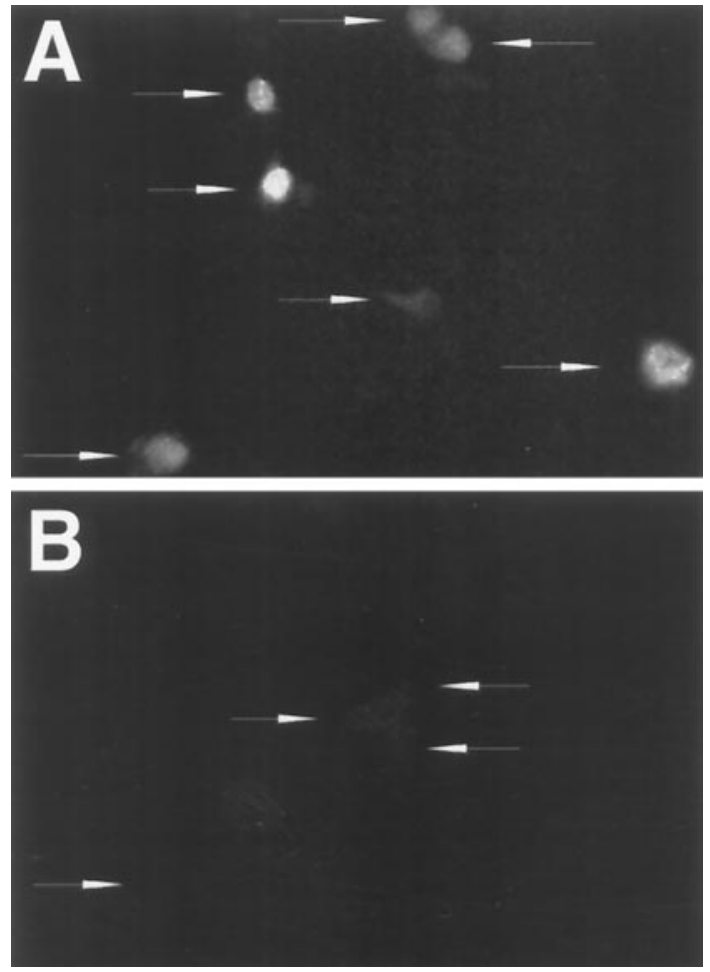

Figure 4. Expression of FLAG-tagged p27 in sympathetic neurons grown in the presence of NGF and infected by an engineered Sindbis virus. $A, B$, Immunofluorescence staining with an antibody directed against the FLAG epitope of neurons in culture infected with Sindbis virus expressing p27-FLAG $(A)$ or containing the p27 control sequence $(B)$. Arrows indicate the locations of individual neurons. Neurons were stained $2 \mathrm{~d}$ after infection.

were engineered to produce the CKIs p21, p16, or p27 (the latter two with or without C-terminal FLAG tags), thereby representing both the p21 and p 27 and the p16 classes of inhibitors. Control viruses were constructed that contained the same transcripts but with the initiation codon deleted and, where appropriate, with a premature stop codon introduced near the $5^{\prime}$ terminal. To confirm expression of the various full-length constructs, we performed immunofluorescent staining with anti-FLAG on sympathetic neurons infected with viruses containing FLAG-tagged proteins. The epitope-tagged p27 protein (Fig. 4) was detected in the nuclei of $95 \%(n=135)$ of the neurons $2 \mathrm{~d}$ after infection. Similar infection efficiency was observed after infection of neurons with p16 flag-expressing virus (data not shown). The degree of expression of the heterologous protein in a given culture was variable (Fig. 4) and may reflect the timing of infection in a given neuron. To confirm expression of heterologous gene expression in sympathetic neurons further, cultures were infected with Sindbis virus containing CAT. CAT activity was detectable in neuronal cultures up to at least $7 \mathrm{~d}$ after infection (data not shown).

Each of the CKI-encoding recombinant viruses, but not the control "noncoding/stop" constructs, promoted the survival of infected sympathetic neurons that were deprived of NGF (Fig. 2). Comparable results were achieved with both untagged and FLAG-tagged constructs. p21 and p27 provided the greatest degree of protection. Two days after NGF deprivation, $\sim 15 \%$ of uninfected or control virus-infected neurons were alive, whereas $\sim 90 \%$ survival was observed for the neurons infected with vi- 

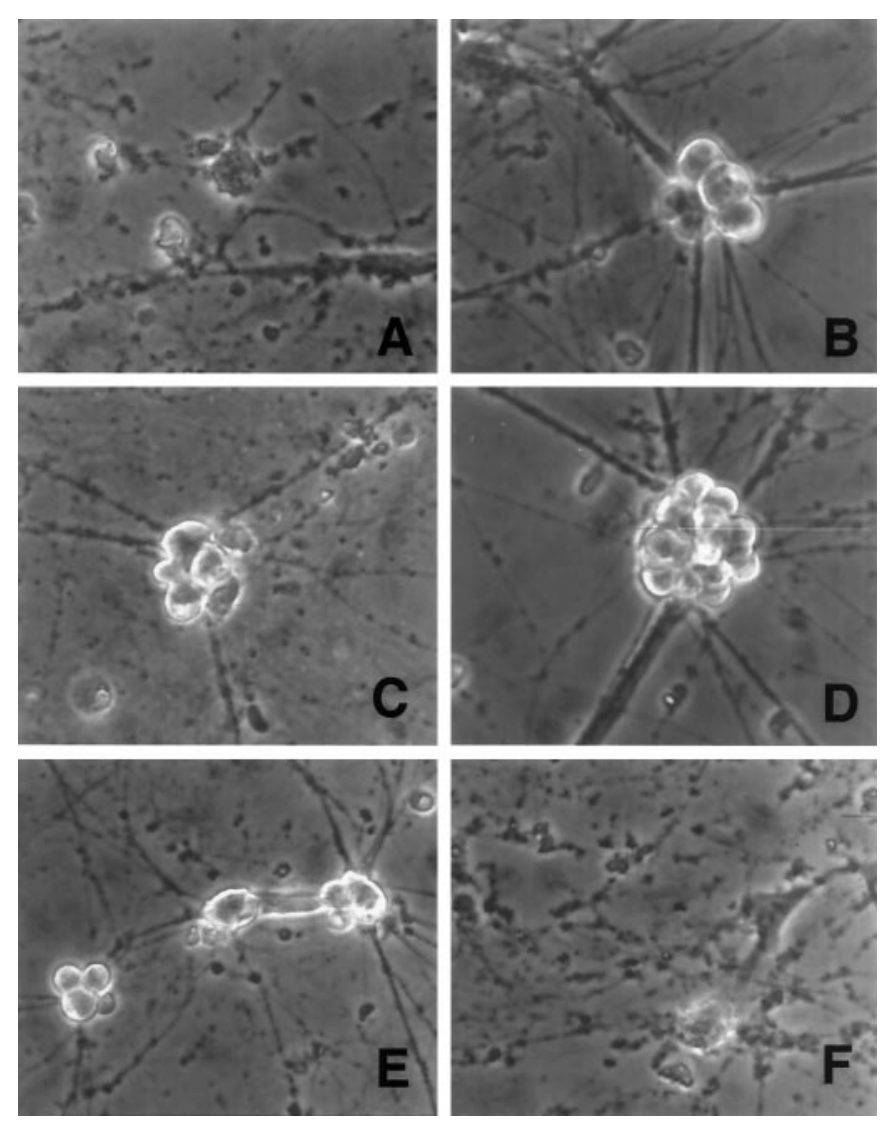

Figure 5. Phase contrast micrographs of rat sympathetic neurons cultured in NGF-free medium in the presence of the following additives for $2 \mathrm{~d}$ : $(A)$ no additives, $(B) \mathrm{NGF},(C)$ p16 Sindbis virus, $(D)$ p21 Sindbis virus, $(E)$ p27 Sindbis virus, and $(F)$ noncoding control Sindbis virus. Magnification, $375 \times$.

ruses encoding p21 and p27. p16 also provided significant protection from NGF deprivation but was consistently less effective than p27 or p21 (50\% survival at $2 \mathrm{~d}$ after NGF deprivation vs $10 \%$ survival in controls). Neurons rescued by the CDK inhibitors displayed phase-bright somata and intact neuritic processes typical of NGF-treated neurons, whereas uninfected or controlinfected neurons displayed degenerated neurites and phase-dark apoptotic ghosts that characterize dying neurons (Fig. 5). The cell bodies of neurons expressing CKIs and deprived of NGF, however, were consistently smaller than those observed in control neurons cultured in the presence of NGF. Death in the presence of NGF was somewhat accelerated for viruses encoding the full-length compared with the control-stop CKIs. The reason for this is presently unclear but could be because of enhancement of viral cytopathic effects or direct effects of the overexpressed CKIs on neuronal survival.

\section{Expression of dominant negative Cdk4 or Cdk6 but not Cdk2 or Cdk3 protects sympathetic neurons from NGF deprivation}

To confirm that the effects of CKI expression were caused, at least in part, by their effect on CDKs and to determine which CDK may play an important role in the death of NGF-deprived neurons, we constructed Sindbis viruses containing dominant negative forms of four CDKs, Cdk2, Cdk3, Cdk4, and Cdk6, all with or without FLAG tags (van den Heuvel and Harlow, 1993).
Dominant negative mutations were previously introduced by an Asp to Asn mutation at the protein kinase KLADFGLAR consensus site (van den Heuvel and Harlow, 1993). Each of these CDKs is associated with $G_{1}$ progression (Pines, 1993; van den Heuvel and Harlow, 1993). Interestingly, although dominant negative $\mathrm{Cdk} 2$ and $\mathrm{Cdk} 3$ have been shown to cause $\mathrm{G}_{1}$ arrest in proliferating U2OS cells, dominant negative $\mathrm{Cdk} 4$ and $\mathrm{Cdk} 6 \mathrm{did}$ not (van den Heuvel and Harlow, 1993). However, constitutive cdk4 expression reduces growth factor requirements of cells released from contact inhibition, and cyclin D1 expression leads to premature S-phase entry (Doree and Galas, 1994). Accordingly, it has been suggested that Cdk4-cyclin D1 activity may control cell cycle progression of cells emerging from quiescence (Doree and Galas, 1994). Expression of each recombinant virus was confirmed by immunofluorescence staining against the FLAG epitope, and expression was detected up to at least $7 \mathrm{~d}$ after infection (data not shown). Sindbis virus constructs expressing dominant negative $\mathrm{Cdk} 2$ or $\mathrm{Cdk} 3$ had no effect on survival of NGF-deprived sympathetic neurons (Fig. 6). In contrast, Sindbis virus-mediated expression of dominant negative $\mathrm{Cdk} 4$ and to a lesser extent Cdk6 significantly delayed death induced by NGF deprivation ( $90 \%$ survival with dominant negative Cdk4 expression vs $50 \%$ in control cultures infected with control virus or uninfected at day 1; 75\% survival with dominant negative Cdk6 expression vs $45 \%$ in the control cultures at day 1; Fig. 6). Comparable results were achieved with both untagged and FLAG-tagged constructs. The appearance of neurons rescued by expression of dominant negative $\mathrm{Cdk} 4$ and $\mathrm{Cdk} 6$ was similar to those rescued by CKI expression (data not shown).

\section{DISCUSSION}

It has been hypothesized previously that postmitotic differentiated neurons use cell cycle regulatory mechanisms as part of the apoptotic pathway activated by trophic factor deprivation (Rubin et al., 1993; Ferrari and Greene, 1994; Freeman et al., 1994; Farinelli and Greene, 1996; Park et al., 1996a,b). To evaluate this hypothesis more definitely, we examined the effects of Sindbis virus-targeted expression of three distinct CKIs (p16, p21, and p27) and of dominant negative forms of four known $G_{1}$ CDKs ( $\mathrm{Cdk} 2, \mathrm{Cdk} 3, \mathrm{Cdk} 4$, and $\mathrm{Cdk} 6)$ on death of primary postmitotic sympathetic neurons evoked by NGF deprivation. We report that Sindbis virus-mediated expression of all three CKIs inhibits death of sympathetic neurons evoked by NGF deprivation and that expression of dominant negative $\mathrm{Cdk} 4$ and $\mathrm{Cdk} 6$ but not Cdk2 and Cdk3 significantly delayed death of NGF-deprived sympathetic neurons.

\section{Sindbis viruses are efficient neuronal-targeting vectors}

The use of Sindbis virus represents an efficient method for targeting heterologous genes to primary postmitotic sympathetic neurons. Previously, the Sindbis virus vector has been used to study the effects of antiapoptotic genes on neuronal death in vivo (Levine et al., 1996). The advantages of Sindbis virus for the study of apoptotic death of primary neurons are several. Stable recombinant viruses can be readily generated within a short period. Once the gene of interest is cloned into the Sindbis vector, viruses can be both produced and titered within $3 \mathrm{~d}$. In addition, because Sindbis is neuronotropic (Levine et al., 1991), essentially all sympathetic neurons in a given culture can be targeted. In addition, we have observed relatively long-term expression (up to at least $7 \mathrm{~d}$ ) of heterologous proteins (as detected 
A

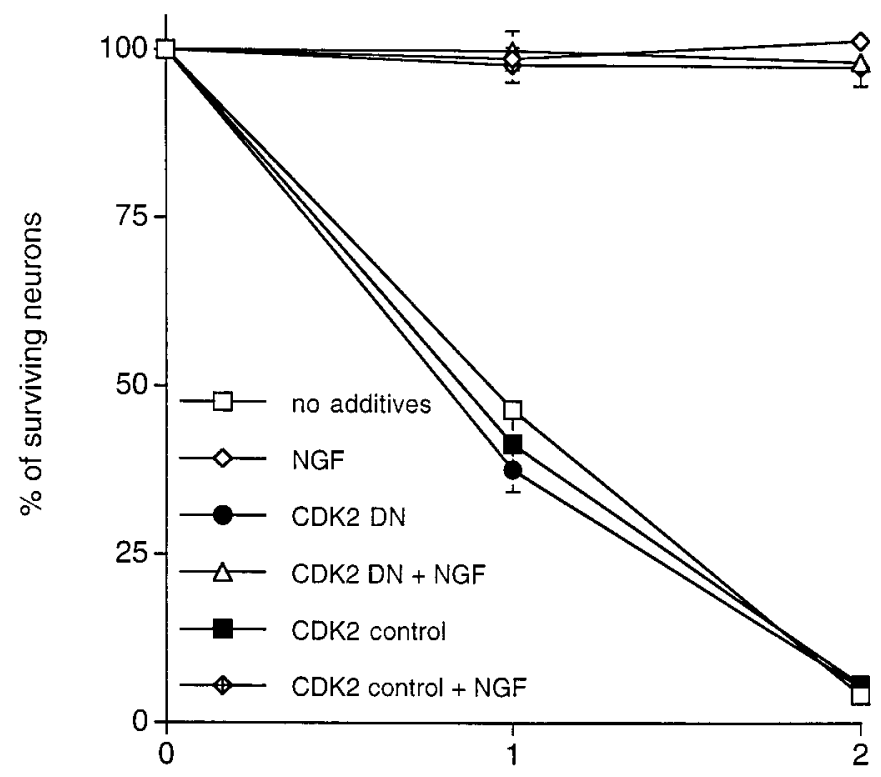

days in the absence of NGF

C

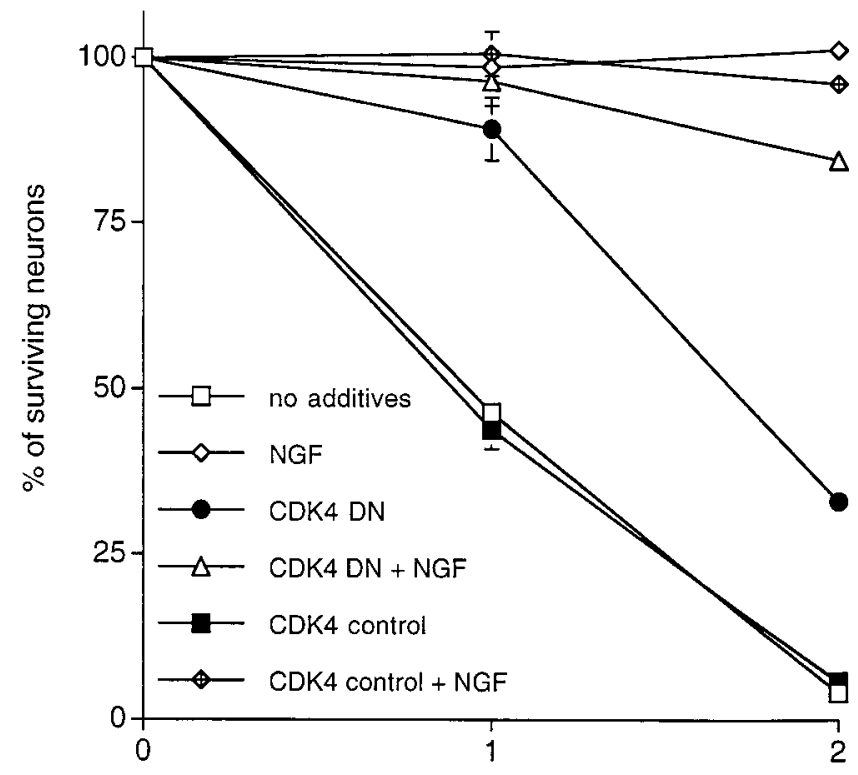

days in the absence of NGF
B

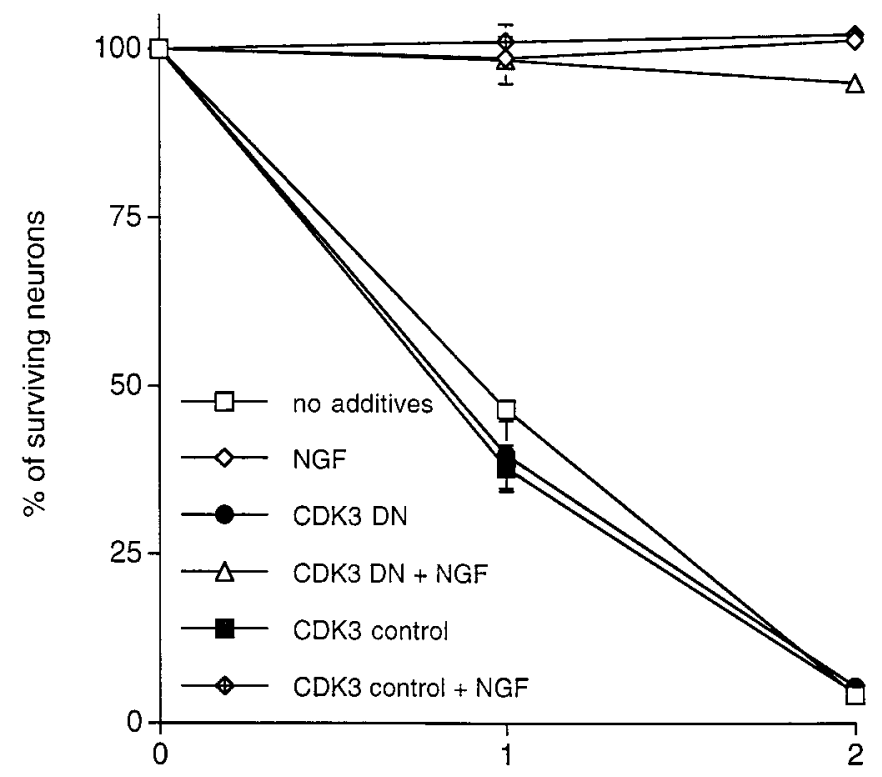

days in the absence of NGF

D

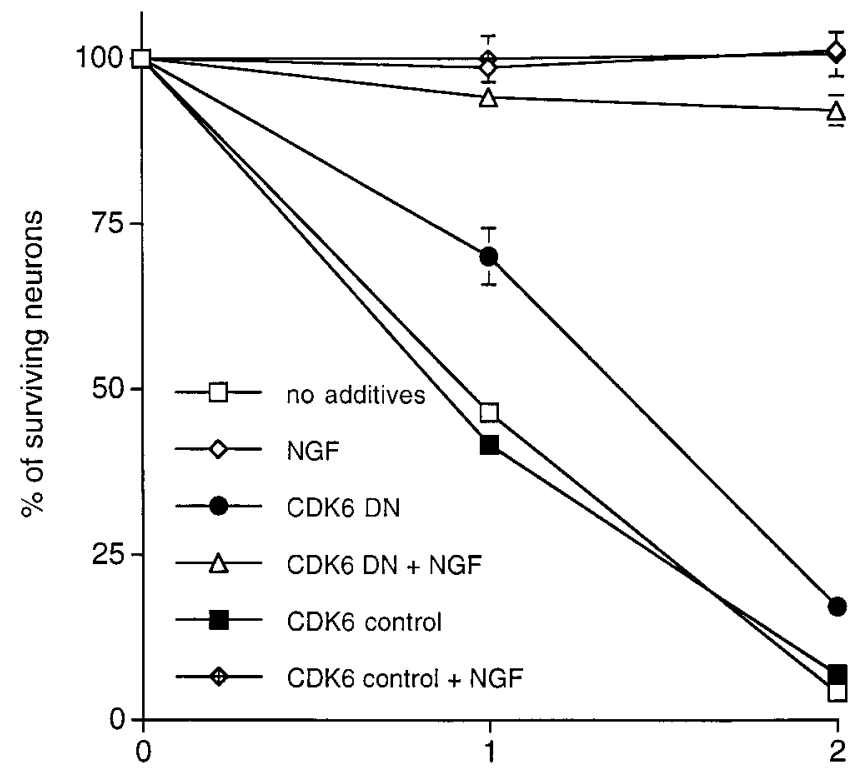

days in the absence of NGF

Figure 6. Expression of dominant negative $\mathrm{Cdk} 4$ and $\mathrm{Cdk} 6$ but not $\mathrm{Cdk} 2$ and $\mathrm{Cdk} 3$ promotes survival of primary cultured sympathetic neurons deprived of trophic support. Each data point is the mean \pm SEM of three samples and is expressed relative to the number of neurons present in each well at the time of NGF withdrawal. Control viruses for each vector were generated by removal of the start codon and, in some cases, by introduction of a premature stop site. $D N$ denotes dominant negative. The values of $p$ derived from Student's $t$ tests comparing the wild-type protein with the control-stop virus at days 1 and 2 are given. $A-D$, Effects of overexpression of DN Cdk2 $(p>0.05)(A), \mathrm{DN} \mathrm{Cdk} 3(p>0.05)(B), \mathrm{DN} \mathrm{Cdk} 4(p<0.01)$ $(C)$, and DN Cdk6 $(p<0.025)(D)$ and respective controls on the time course of survival of sympathetic neurons after withdrawal of NGF. Similar results were obtained in at least three independent experiments.

by CAT activity or immunofluorescence) expressed from Sindbis virus. It must be stressed, however, that care must be taken to diminish the possibility that the virus itself causes unwanted experimental artifacts and possible survival effects. Because it is conceivable that the inherent nature of the foreign insert may alter the characteristics of Sindbis virus, we created for each gene of interest an appropriate stop/control virus. We demonstrated that these stop/control viruses, along with several other recombinant viruses expressing nonapoptotic-related genes, had minimal effect on the death of sympathetic neurons evoked by NGF 
deprivation. In contrast, viruses expressing the antiapoptotic genes $b c l-2$ and $b c l-x_{L}$ conferred protection against NGF deprivation. Accordingly, it is unlikely that effects of Sindbis virus infection, itself, account for the protective effects observed with expression of the CKIs or dominant negative CDKs.

\section{Cell cycle components and apoptotic death}

Several lines of evidence have implicated cyclins and CDKs in apoptosis of proliferation-competent cell lines. In proliferating cells, multiple agents that induce apoptosis also upregulate cyclin A-associated CDK activity (Hoang et al., 1994; Meikrantz et al., 1994), and expression of dominant negative mutants of $\mathrm{Cdc} 2$, $\mathrm{Cdk} 2$, and Cdk3 suppresses apoptosis in HeLa cells (Meikrantz and Schlegel, 1996). Moreover, it has been reported that NGF deprivation leads to increased Cdc2 activity and cyclin B expression in neuronal PC12 cells (Brooks et al., 1993; Gao and Zelenka, 1995), that expression of the CKI p21 is required for survival of differentiated neuroblastoma cells (Poluha et al., 1996), and that CKI p16 protects these cells from death caused by trophic factor deprivation (Kranenburg et al., 1996).

Although the above findings are suggestive and support a role for cell cycle molecules in the apoptotic process of transformed and proliferation-competent cells, it should be stressed that they are not necessarily directly applicable to postmitotic cells such as neurons. We therefore used Sindbis virus to express CKIs and dominant negative CDKs in sympathetic neurons and observed protection from death evoked by NGF deprivation. These findings conform to the predictions of the neuronal cell cycle model and previous findings implicating the action of one or more CDKs in neuronal apoptosis. They are also consistent with previous observations that pharmacological inhibitors of CDK activity block death of NGF-deprived sympathetic neurons and neuronally differentiated PC12 cells at the same concentrations at which they block thymidine incorporation by proliferating PC12 cells (Park et al., 1996a).

In addition to its CDK inhibitory activity, p21 has been shown to bind PCNA and to block Jun kinase activity (Shim et al., 1996). Activation of c-jun has been suggested to play a required role in certain cases of cell death, including that evoked by NGF deprivation in PC12 cell cultures (Xia et al., 1995). However, the abilities of p27 and p16 [a member of an entirely different CKI family that does not inhibit Jun kinase activity (Shim et al., 1996)] to suppress apoptosis in our experiments favor a mechanism in which all three CKIs act via their inhibitory interactions with CDKs and CDK-cyclin complexes. p16 preferentially blocks cyclin D-associated kinases Cdk4 and Cdk6 (Sherr and Roberts, 1995). This is consistent with the observation that cyclin D1 levels increase after death of sympathetic neurons (Freeman et al., 1994).

To support our observations with CKI expression further as well as to determine which $\mathrm{CDK}(\mathrm{s})$ may play a role in neuronal death, we examined the effects of expression of dominant negative forms of four known $\mathrm{G}_{1}$-associated CDKs. We show that expression of dominant negative $\mathrm{Cdk} 4$ and $\mathrm{Cdk} 6$ but not $\mathrm{Cdk} 2$ and $\mathrm{Cdk} 3$ delays the death of NGF-deprived sympathetic neurons. These findings are again consistent with those observed with the CKIs in the present study and with previous reports showing an induction of cyclin D1 transcripts in sympathetic neurons (Freeman et al., 1994) and the presence in these cells of transcripts for Cdk4 but not Cdk2 (Freeman et al., 1994). It is presently unknown whether $\mathrm{Cdk} 3$ or Cdk6 are present in sympathetic neurons. Although expression of dominant negative
CDK4 and Cdk6 delayed death of NGF-deprived sympathetic neurons, complete attenuation of death was not achieved. This may be because of the requirement for higher levels of expression of the dominant negative CDKs or the involvement of other signaling elements that act in conjunction with CDK activation to signal neuronal apoptosis. The latter would be consistent with the lesser effectiveness of p16 in comparison with p21 and $\mathrm{p} 27$.

Although the potential function of $\mathrm{Cdk} 4$ and Cdk6 in the context of a dying sympathetic neuron is unknown, it is interesting to note that one well studied substrate of Cdk4 and Cdk6 is the retinoblastoma gene $(\mathrm{RB})$. pRB, the product of the retinoblastoma tumor suppressor gene, is thought to play a role in regulating the $G_{1}$ phase of the cell cycle (Chellepan et al., 1991; Weinberg, 1995). Phosphorylation is thought to control its interaction with at least one known binding partner, E2F. Interestingly, expression of $\mathrm{pRB}$ in many different cellular contexts, including neurons, is protective against apoptosis (Berry et al., 1996; Fan et al., 1996; Macleod et al., 1996), whereas loss of pRB interaction leads to activation of death programs (Liu and Kitsis, 1996; Shan et al., 1996). Finally, RB knock-out mice display disrupted CNS development and neuronal cell death (Jacks et al., 1992). Accordingly, the functional state of RB, perhaps mediated via phosphorylation by $\mathrm{CDKs}$, may play an important role in signaling neuronal death.

The potential role of cell cycle elements in neuronal death may not be limited to the paradigm of NGF deprivation. The CDK inhibitor drugs flavopiridol and olomoucine also block apoptosis of sympathetic neurons evoked by various DNA-damaging conditions (Park et al., 1997) (D. S. Park and L. A. Greene, unpublished data). However, CDK activity does not seem likely to be required in all cases of neuronal cell death, because olomoucine and flavopiridol have no effect on death of sympathetic neurons evoked by superoxide dismutase 1 depletion (D. S. Park, C. M. Troy, L. A. Greene, and M. L. Shelanski, unpublished data).

Apoptosis of neurons caused by trophic factor deprivation seems to be mediated by multistep pathways. In addition to cell cycle components, other elements of neuronal apoptotic pathways include death regulatory molecules such as Bcl-2 (Batistatou et

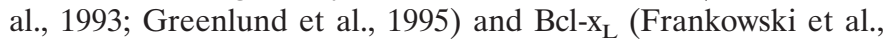
1996) as well as death effector caspases such as Nedd2/Ich-1 (Troy et al., 1997). This raises the question as to where these molecules lie in the apoptotic pathway relative to one another. Previous evidence indicates that both $\mathrm{Bcl}-2$ and $\mathrm{CDK}$ activations are upstream of caspase activation in neuronally differentiated PC12 cells (Stefanis et al., 1996). However, in these cells, Bcl-2 overexpression does not seem to affect proliferative capacity and therefore may act in parallel with or downstream of cell cycle components. It is yet unclear how the activity of Cdk4 and Cdk6 and perhaps the phosphorylation of $\mathrm{pRB}$ may lead to activation of the caspases.

In summary, we report that CK Is and dominant negative Cdk4 and Cdk6 inhibit the death of primary neurons deprived of neurotrophic support. Our data suggest that CDK activation may be a required element in the mechanism by which trophic factor deprivation triggers neuronal death.

\section{REFERENCES}

Batistatou A, Greene LA (1993) Internucleosomal DNA cleavage and neuronal cell survival/death. J Cell Biol 122:523-532.

Batistatou A, Merry DE, Korsmeyer SJ, Greene LA (1993) Bcl-2 affects 
survival, but not neuronal differentiation of PC12 cells. J Neurosci 13:4422-4428.

Berry DE, Lu Y, Schimdt B, Falon PG, O'Connell C, Hu S-X, Xu H-J, Blanck G (1996) Retinoblastoma protein inhibits IFN induced apoptosis. Oncogene 12:1809-1819.

Brooks SF, Gibson LA, Rubin LL (1993) Apoptosis induced by NGFwithdrawal from differentiated $\mathrm{PC} 12$ cells involves activation of P34cdc2 kinase. Soc Neurosci Abstr 19:885.

Chellepan SP, Hiebert S, Mudryj M, Horowitz JM, Nevins JR (1991) The E2F transcription factor is a cellular target for the RB protein. Cell 65:1053-1061.

Cheng EHY, Levine B, Boise LH, Thompson CB, Hardwick JM (1996) Bax-independent inhibition of apoptosis by Bclx-L. Nature 379:554-556.

Deckworth TL, Elliot JL, Knudson CM, Johnson Jr EM, Snider WD, Korsmeyer SJ (1996) BAX is required for neuronal death after trophic factor deprivation and during development. Neuron 17: 401-411.

Doree M, Galas S (1994) The cyclin-dependent protein kinases and the control of cell division. FASEB J 8:1114-1121.

Edwards SN, Buckmaster AE, Tolkovsky AM (1991) The death programme in cultured sympathetic neurones can be suppressed at the post-translational level by nerve growth factor, cyclic AMP, and depolarization. J Neurochem 57:2140-2143.

Estus S, Zaks WJ, Freeman RS, Gruda M, Bravo R, Johnson Jr EM (1994) Altered gene expression in neurons during programmed cell death: identification of c-jun as necessary for neuronal apoptosis. J Cell Biol 127:1717-1727.

Fan G, Ma X, Kren BT, Steer CJ (1996) The retinoblastoma gene product inhibits TGF-b1 induced apoptosis in rat hepatocyte and human HuH-7 hepatoma cells. Oncogene 12:1909-1919.

Farinelli SE, Greene LA (1996) Cell cycle blockers mimosine, ciclopirox, and deferoxamine prevent the death of PC12 cells and postmitotic sympathetic neurons after removal of trophic support. J Neurosci 16:1150-1162.

Ferrari G, Greene LA (1994) Proliferative inhibition by dominantnegative Ras rescues naive and neuronally-differentiated PC12 cells from apoptotic death. EMBO J 13:5922-5928.

Frankowski H, Missotten M, Fernandez PA, Martinou I, Michel P, Sadoul XR, Martinou JC (1995) Function and expression of the $b c l-x$ gene in the developing and adult nervous system. NeuroReport 6:1917-1921.

Freeman RF, Estus S, Johnson Jr EM (1994) Analysis of cell-related gene expression in postmitotic neurons: selective induction of Cyclin D1 during programmed cell death. Neuron 12:343-355.

Gagliardini V, Fernandez P-A, Lee RKK, Drexler HCA, Rotello RJ, Fishman MC, Yuan J (1994) Prevention of vertebrate neuronal death by the $\mathrm{crm} A$ gene. Science 263:826-828.

Gao CY, Zalenka PS (1995) Induction of cyclin B and H1 kinase activity in apoptotic PC12 cells. Exp Cell Res 219:612-618.

Gorin PD, Johnson Jr EM (1979) Experimental auto-immune model of nerve growth factor deprivation: effects on developing peripheral sympathetic and sensory neurons. Proc Natl Acad Sci USA 76:5382-5386.

Gorin PD, Johnson Jr EM (1980) Effects of long-term nerve growth factor deprivation on the nervous system of the adult rat: an experimental autoimmune approach. Brain Res 198:27-42.

Greenlund LJS, Korsmeyer SJ, Johnson Jr EM (1995) Role of Bcl-2 in the survival and function of developing and mature sympathetic neurons. Neuron 15:649-661.

Hahn CS, Hahn YS, Braciale TJ, Rice CM (1992) Infectious Sindbis virus transient expression vectors for studying antigen processing and presentation. Proc Natl Acad Sci USA 89:2679-2683.

Ham J, Babji C, Whitfield J, Pfarr CM, Lallemand D, Yaniv M, Rubin LL (1995) A c-jun dominant negative mutant protects sympathetic neurons against programmed cell death. Neuron 14:927-939.

Hoang AT, Cohen KJ, Barrett JF, Bergstrom DA, Dang CV (1994) Participation of cyclin A in Myc-induced apoptosis. Proc Natl Acad Sci USA 91:6875-6879.

Jacks T, Fazeli A, Schitt EM, Bronson RT, Goodell MA, Weinberg RA (1992) Effects of an Rb mutation in the mouse. Nature 359:295-300.

Jackson AC, Moench TR, Griffin DE, Johnson RT (1987) The pathogenesis of spinal cord involvement in the encephalomyelitis of mice caused by neuroadapted Sindbis virus infection. Lab Invest 56:418-423.

Jackson AC, Moench TR, Trapp BD, Griffin DE (1988) Basis of neurovirulence in Sindbis virus encephalomyelitis of mice. Lab Invest 58:503-509.

Joe AK, Ferrari G, Jiang HH, Liang XH, Levine B (1996) Dominant inhibitory Ras delays sindbis virus-induced apoptosis in neuronal cells. J Virol 70:7744-7751.

Kranenburg O, van der Eb AJ, Zantema A (1996) Cyclin D1 is an essential mediator of apoptotic neuronal cell death. EMBO J 15:46-54.

Levi-Montalcini R, Angeletti PU (1963) Essential role of the nerve growth factor in the survival and maintenance of dissociated sensory and sympathetic embryonic nerve cells in vitro. Dev Biol 7:653-659.

Levi-Montalcini R, Booker B (1960) Destruction of sympathetic ganglia in mammals by antiserum to a nerve growth factor protein. Proc Natl Acad Sci USA 46:384-391.

Levine B, Hardwick JM, Trapp BD, Crawford TO, Bollinger RC, Griffin DE (1991) Antibody-mediated clearance of alphavirus infection from neurons. Science 254:856-860.

Levine B, Hunag Q, Isaacs JT, Reed JC, Griffin DE, Hardwick JM (1993) Conversion of lytic to persistent alphavirus infection by the bcl-2 cellular oncogene. Nature 361:739-742.

Levine B, Goldman JE, Jiang HH, Griffin DE, Hardwick JM (1996) Bcl-2 protects mice against fatal alphavirus encephalitis. Proc Natl Acad Sci USA 93:4810-4815.

Liu Y, Kitsis RN (1996) Induction of DNA synthesis and apoptosis in cardiac myocytes by E1A oncoprotein. J Cell Biol 133:325-334.

Macleod KF, Hu Y, Jacks T (1996) Loss of RB activates both p53dependent and independent cell death pathways in the developing mouse nervous system. EMBO J 15:6178-6188.

Martin D, Schmidt R, DiStefano P, Lowry O, Carter J, Johnson Jr EM (1988) Inhibitors of protein synthesis and RNA synthesis prevent neuronal death caused by nerve growth factor deprivation. J Cell Biol 106:829-844.

Meikrantz W, Schlegel R (1996) Suppression of apoptosis by dominant negative mutants of cyclin-dependent protein kinases. J Biol Chem 271:10205-10209.

Meikrantz W, Gisselbrecht S, Tam SW, Schlegel R (1994) Activation of cyclin A-dependent protein kinases during apoptosis. Proc Natl Acad Sci USA 91:3754-3758.

Oppenheim RW (1991) Cell death during the development of the nervous system. Annu Rev Neurosci 14:453-501.

Park DS, Farinelli SE, Greene LA (1996a) Inhibitors of cyclin dependent kinases promote survival of post-mitotic neuronally differentiated PC12 cells and sympathetic neurons. J Biol Chem 271:8161-8169.

Park DS, Stefanis L, Yan CYI, Farinelli SE, Greene LA (1996b) Ordering the cell death pathway: differential effects of Bcl-2, an interleukin1-converting enzyme family protease inhibitor, and other survival agents on JN K activation in serum/nerve growth factor-deprived PC12 cells. J Biol Chem 271:21898-21905.

Park DS, Morris EJ, Greene LA, Geller HM (1997) G1/S cell cycle blockers and inhibitors of cyclin dependent kinases suppress camptothecin-induced apoptosis. J Neurosci 17:1256-1270.

Pines J (1993) Cyclins and cyclin-dependent kinases: take your partners. Trends Biochem Sci 18:195-197.

Piper RC, Tai C, Slot JW, Han CS, Rice CM, Huang H, James DE (1992) The efficient intracellular sequestration of the insulinregulatable glucose transporter (GLUT-4) is conferred by the NH2terminus. J Cell Biol 117:729-743.

Poluha W, Poluha DK, Chang B, Crosgie NE, Schonoff CM, Kilpatrick DL, Ross AH (1996) The cyclin-dependent kinase inhibitor p21waf1 is required for survival of differentiating neuroblastoma cells. Mol Cell Biol 16:1334-1341.

Rubin LL, Philpott KL, Brooks SF (1993) The molecular mechanisms of neuronal apoptosis. Curr Opin Neurobiol 3:391-394.

Rydel RE, Greene LA (1988) cAMP analogs promote survival and neurite outgrowth in cultures of sympathetic and sensory neurons independently of nerve growth factor. Proc Natl Acad Sci USA 85:1257-1261.

Schlesinger S (1993) Alphaviruses-vectors for the expression of heterologous genes. TIBTECH 11:18-22.

Shan B, Durfee T, Lee W-H (1996) Disruption of RB/E2f-1 interaction 
by a single point mutation in E2f-1 enhances S-phase entry and apoptosis. Proc Natl Acad Sci USA 93:679-684.

Sherr CJ, Roberts JM (1995) Inhibitors of mammalian G1 cyclindependent kinases. Genes Dev 9:1149-1163.

Shim J, Lee H, Park J, Kim H, Choi E-J (1996) A non-enzymatic p21 protein inhibitor of stress-activated protein kinases. Nature 381:804-806.

Stefanis L, Park DS, Yan CYI, Farinelli SE, Troy CM, Shelanski ML, Greene LA (1996) Induction of CPP32-like activity in PC12 cells by withdrawal of trophic support: dissociation from apoptosis. J Biol Chem 271:30663-30671.

Stefanis L, Burke RE, Greene LA (1997) Apoptosis in neurodegenerative Disorders. Curr Opin Neurol 10:299-305.

Troy CM, Stefanis L, Green LA, Shelanski ML (1997) Nedd2 is re- quired for apoptosis after trophic support withdrawal, but not superoxide dismutase (SOD1) downregulation, in sympathetic neurons and PC12 cells. J Neurosci 17:1911-1918.

van den Heuvel S, Harlow E (1993) Distinct roles for cyclin-dependent kinases in cell cycle control. Science 262:2050-2054.

Weinberg RA (1995) The retinoblastoma protein and cell cycle control. Cell 81:323-330.

Xia Z, Dickens M, Raingeaud J, Davis RJ, Greenberg ME (1995) Opposing effects of ERK and JNK-p38 MAP kinases on apoptosis. Science 270:1321-1326.

Xiong C, Levis R, Shen P, Schlesinger S, Rice CM, Huang HV (1989) Sindbis virus: an efficient, broad host range vector for gene expression in animal cells. Science 243:1188-1191. 